\title{
Cardiac Germ Cell Tumor
}

National Cancer Institute

\section{Source}

National Cancer Institute. Cardiac Germ Cell Tumor. NCI Thesaurus. Code C147005.

A germ cell tumor that arises within the myocardium or cardiac chambers. The reported cases have been teratomas and yolk sac tumors. 